Ключевые слова: этанол, ацетальдегид, алкогольная интоксикация, макро- $и$ микроэлементы, лабораторная диагностика, судебно-медицинская экспертиза.

\title{
OBJECTIFICATION OF LABORATORY DIAGNOSTICS OF ACUTE AND CHRONIC ALCOHOL INTOXICATION BY USING MODERN BIOCHEMICAL MARKERS
}

\section{Derecha L. M., Myasoedov V. V., Bondarenko V. V.}

The paper deals with the problem of alcoholic illness-pathology which become recently widespread in many countries and ranks third among causes of death and disability after cardiovascular and cancer diseases. Key issues of pathogenesis, clinics and diagnostics of the most common affections of internal organs of alcoholic etiology are highlighted; special attention is paid to the laboratory methods for diagnosis of chronic intoxication by alcohol. On the basis of data analysis of experiments on cadaveric material, criteria for the diagnosis of death from alcohol poisoning by determining levels of potassium, sodium, calcium, magnesium, zinc and copper in the organs and tissues, are developed. By analyzing results of the research, it can be concluded that the more informative indicators in comparison with the absolute values are the ratios of concentrations of elements in blood serum. Thus, the ratio of $\mathrm{Na} / \mathrm{K}$ and $\mathrm{Ca} / \mathrm{Mg}$ was 34.03, and 4.18, respectively, that is in 1.44 times higher than in a control group; ratio of $\mathrm{Cu} / \mathrm{Zn}-1.36$, that is in 1.68 times higher than in a control group. Thus, the ratios of $\mathrm{Na} / \mathrm{K}, \mathrm{Ca} / \mathrm{Mg}$ and $\mathrm{Cu} / \mathrm{Zn}$ in blood serum of persons who died from poisoning by etanolom, is increased in comparison with the control group. It's shown that the informative indicator of alcohol poisoning is also the presence of the concentration of acetaldehyde in the blood in the amount of $0.02 \%$ and over (+6.4), that gives grounds to consider this indicator like an additional diagnostic criterion for alcohol poisoning. The study results allowed to define that one of the ways to optimize expert evaluation of alcohol poisoning is the use of the proposed additional biochemical markers of alcohol poisoning which make it possible to increase the objectivity and accuracy of forensic medical diagnostics of this type of death.

Keywords: forensic medical examination, effect of ethanol on the organism, macroand microelements, acetaldehyde, laboratory diagnostics.

I. М. Козаченко, доцент кафедри судовомедичної експертизи Харківської медичної академії післядипломної освіти, кандидат медичних наук

\section{ВИЗНАЧЕННЯ ВИДУ ТА МАРКИ СНАРЯДІВ МЕТОДОМ РЕНТГЕНОФЛУОРЕСЦЕНТНОГО СПЕКТРАЛЬНОГО АНАЛІЗУ ПРИ ДОСЛІДЖЕННІ ПНЕВМОСТРІЛЬНИХ ПОШКОДЖЕНЬ ДЕЯКИХ МАТЕРІАЛІВ ОДЯГУ}

Виконано рентгенофлуоресиентний спектральний якісний $і$ кількісний аналізи елементного складу 4-х марок куль до пневматичної зброї вітчизняного й іноземного виробництв, а також імітаторів поширених матеріалів одягу - камуфльованої тканини та бавовняного трикотажу. Визначено, 
щзо свинцеві кулі до пневматичної зброї здатні привносити до пошкоджень на окремих матеріалах одягу, зокрема на камуфльованій тканині та бавовняному трикотажі, деякі елементи зі свого складу, які притаманні лише тій чи інший мариі кулі. Це розширює можливості судово-медичної експертизи під час вирішення питання щодо визначення виду й марки кулі або невеликої групи схожих за елементним складом куль, які заподіяли пневмострільні пошкодження на досліджуваних об'єктах.

Ключові слова: рентгенофлуоресиентний спектральний аналіз, елементний склад, кулі калібру 4,5 мм, пневмострільні пошкодження, камуфльована тканина, бавовняний трикотаж.

Рентгенофлуоресцентний спектральний аналіз (РФСА) ${ }^{1}$ має високу чутливість і точність, що дозволяє проводити якісний і кількісний аналізи всіх хімічних елементів, які входять до складу речовини, від фтору до урану, до того ж без будь-якого змінення об'єкта. Для реалізації РФСА промисловістю різних країн виробляються численні прилади, серед яких вітчизняні аналізатори ЕКОЛОГ серії Expert, які крім визначення в об’єкті якісного складу хімічних елементів вимірюють їх масові частки. В аналізаторі елементного складу Expert 3XL реалізовано методику енергодисперсійного рентгенофлуоресцентного елементного аналізу методом фундаментальних параметрів зі збудженням характеристичного випромінювання атомів проби фотонами гальмівного спектра малопотужної рентгенівської трубки та регістрацією цього випромінювання напівпровідниковим PIN-детектором із термоелектричним охолодженням.

Цей метод останнім часом застосовується в ході дослідження пошкоджень об'єктів судово-медичної та криміналістичної експертизи, заподіяних пострілами із різних видів ствольної зброї, причому не тільки з найбільш поширеної вогнепальної, а також із так званої «зброї нелетальної дії» або травматичної діï (курсив наш - I. K.) $)^{2}$. Рентгеноспектральний флуоресцентний аналіз використовується при дослідженні пневмострільних пошкоджень різних об'єктів судово-медичної та криміналістичної експертизи, оскільки

1 У спеціальній літературі можна зустріти й інши назви: рентгенофлуоресцентний аналіз (РФА), рентгеноспектральний флуоресцентний аналіз (РСФА), рентгенофлуоресцентна спектроскопія (англ. X-ray fluorescence spectroscopy, XRFS), хоча йдеться про один і той самий метод.

2 Див.: Олейник В. П. Использование анализаторов рентгеновского спектра в целях экспрессдиагностики металлов в следах повреждений : практ. рекомендации / В. П. Олейник, Т. М. Самойлова. - СПб., 1994; Havel J. Energie disperzní rentgenová fluorescenční spektrometrie - forenzní chemie metoda pro detekci reziduí kuličky kovu v střelnými ranami / J. Havel, K. Zelenka // Soud. Lek. — 2003, Apr. — № 48(2). — P. 22 27; Бабаханян A. Р. Судебно-медицинские аспекты повреждений, причиненных из оружия нелетального действия / А. Р. Бабаханян, Р. В. Бабаханян, В. Д. Исаков // Судеб.-мед. эксперт. - 2005. - № 4. - С. 5-8; Привнесение химических элементов в трикотажные ткани в случаях применения травматического газового оружия с резиновыми пулями / [В. В. Пудовкин, А. В. Воронин, Р. Р. Мингалимов и др.] // Судеб.мед. эксперт. - 2007. - № 2. - С. 25-28. 
цей метод дозволяє оперативно і з високою точністю визначати елементний склад досліджуваного об'єкта, залишаючи його в незмінному стані.

С. А. Райзбергом зі співавторами проведено експериментальне дослідження 3 метою визначення особливостей дії продуктів пострілу з пневматичної гвинтівки Big Bore 909 S калібру 9 мм (виробництва компанії Sam Yang, Південна Корея) із системою попереднього накачування повітря (PSP). Постріли по перешкодах із білої бязі з відстані 100 см виконували штатними свинцевими безоболочними кулями виробництва компанії Air Venturi (США), які розрізнялися лише за формою головної частини (ГЧ). За цією ознакою їx поділили на три групи: I - iз напівсферичною ГЧ; II - iз пласкою ГЧ; III iз п’ятикутною заглибеною в центрі ГЧ. Одним із методів, використаних під час дослідження, був РФСА. За допомогою рентгенівського кристал-дифракційного спектрометра SPECTROSCAN-MAKS GV визначали хімічні елементи, що входять до складу куль I-III груп, а також привнесені в зони країв експериментальних пошкоджень перешкод.

Вони встановили, що до складу куль I-III групи входять $\mathrm{Pb}, \mathrm{Cu}, \mathrm{Fe}, \mathrm{Sn}$, а куль II і III груп - ще й Sb. Виявлена більша кількість свинцю в складі куль I групи (у 3,1 і 2,7 рази на відміну від куль II й III груп відповідно), а також на ділянках пошкоджень від цих куль на перешкодах. У кулях III групи більше міді у 2,4 та 1,3 рази, ніж у кулях I й II груп відповідно), заліза (відповідно в 1,2 та 1,1 рази, ніж у кулях I й II груп) і олова (у 1,2 та 10,3 рази, ніж у кулях I й II груп відповідно). Цих же елементів було більше на ділянці пошкоджень на перешкодах, сформованих кулями III групи. На думку авторів, розбіжності в якісних і кількістних характеристиках елементного складу застосованих куль залежать від форми їх головної частини‥ Із цим твердженням не можна погодититися, оскільки сама форма ГЧ кулі жодним чином не може вплинути на її елементний склад. Оскільки склад куль до пневматичної зброї (ПЗ) визначаєтся передусім їх цільовим призначенням, то в цьому випадку наявність великої кількості олова в кулях III групи із заглибиною в ГЧ, тобто експансивних, зумовлена завданням виробника виготовити «м'який» снаряд, для підвищення його уражаючих властивостей. Також не є безперечним обрання матеріалу для перешкод, у який здійснювали експериментальні постріли, білої бавовняної тканини - бязі, як імітатора тканини одягу. Цей матеріал завдяки своїм властивостям традиційно використовуєтся для експериментальних пострілів зі ствольної зброї, але нині для виготовлення верхнього одягу та навіть нижньої білизни, як у минулому, практично не використовується ${ }^{2}$. На наш погляд, для імітаторів

1 Див.: Райзберг C. А. Судебно-медицинская характеристика факторов выстрела и повреждений, причиненных из 9,0 мм пневматической винтовки / С. А. Райзберг, И. Ю. Макаров, А. С. Лоренц // Судеб.-мед. эксперт. - 2012. — № 3. - С. 4-8.

2 Див.: Козаченко I. M. Оптимізація вибору матеріалів-імітаторів одягу для експериментальних досліджень ушкоджень зі ствольної зброї / I. М. Козаченко // Питання судової медицини та експертної практики : XI зб. наук. пр., присвяч. 90-річчю Донец. обл. бюро суд.-мед. експертизи та 60-річчю каф. суд. медицини Донец. нац. мед. ун-ту. - Донецьк, 2013. - С. 150-152. 
одягу під час експериментів зі ствольною зброєю потрібно використовувати сучасні поширені серед населення матеріали.

Нами методом РФСА досліджено 13 найбільш поширених в Україні марок вітчизняних і зарубіжних снарядів до ПЗ калібру 4,5 мм. У складі цих снарядів виявлено 20 різних елементів, серед яких $\mathrm{Cl}, \mathrm{Ca}, \mathrm{Cr}, \mathrm{Mn}, \mathrm{Fe}, \mathrm{Ni}, \mathrm{Cu}$, $\mathrm{Zn}, \mathrm{Ga}, \mathrm{As}, \mathrm{Sr}, \mathrm{Y}, \mathrm{Zr}, \mathrm{Cd}, \mathrm{Sn}, \mathrm{Sb}, \mathrm{I}, \mathrm{Os}, \mathrm{Ir}, \mathrm{Pb}$. Означені елементи в різних комбінаціях зустрічалися в досліджуваних снарядах, причому якоїсь залежності елементного складу від форми головної частини виявлено не було. Установлено, що всі снаряди містять основний метал сплаву (основу), якою для свинцевих куль $€$ свинець $(\mathrm{Pb})$, для комбінованих із осердям - мідь $(\mathrm{Cu})$, для куль типу $\mathrm{BB}$ - залізо + мідь ( $\mathrm{Fe}, \mathrm{Cu})$. Інші виявлені елементи є лігатурами, тобто домішками, що додаються до сплаву для надання твердості й «жорсткості», або навпаки «м'якості» та легкості (сурма, олово, мідь, кремній тощо) і так званим примолом від форм (залізо, титан, нікель, хром тощо), що залишився на всіх кулях унаслідок контакту із прес-формою або вальцями під час їх виготовлення ${ }^{1}$.

Mema cmammi - визначити за допомогою РФСА елементний склад окремих снарядів до ПЗ калібру 4,5 мм, а також наявність аналогічних елементів у експериментальних пневмострільних пошкодженнях на імітаторах деяких тканин одягу, що дасть змогу визначити марку снаряда або групу схожих за складом снарядів за слідами на об'єктах судово-медичної та криміналістичної експертизи.

Для дослідження використовувався програмно-аналітичний комплекс, до складу якого входять: аналізатор елементного складу Expert 3XL (HBП «Інститут аналітичних методів контролю», Київ), призначений для вимірювання масових часток хімічних елементів у однорідних об'ємних пробах неруйнівним методом рентгенофлуоресцентного аналізу; персональний комп'ютер і принтер. Власне аналізатор Expert 3XL складається з блоку вимірювання (БВ) та блоку обробки (БО).

Досліджувалися 4 марки поширених в Україні свинцевих снарядів до ПЗ вітчизняного та іноземного виробництв калібру 4,5 мм: куля суцільнометалева розширювальна ковпачкова ${ }^{2}$ - ЛЮМАН Field Target 0.68 g (Україна $)^{3}$, кулі суцільнометалеві розширювальні типу «діаболо»-Scarabey DS 0.62 g (Україна), Crosman Premier 0.68 g (США), Diabolo Standard (Чехія). Для отримання експериментальних пошкоджень в імітаторі матеріалів одягу використали пневматичну гвинтівку калібру 4,5 мм Diana-350 Magnum (Німеччина). Імітаторами матеріалів одягу слугували поширена в Україні

1 Див.: Козаченко I. M. Застосування рентгенофлуоресцентного спектрального аналізу при визначенні виду та марки снарядів до пневматичної зброї / I. М. Козаченко // Теорія та практика судової експертизи і криміналістики : зб. наук. пр. - Х. : Право, 2012. - Вип. 11. - С. 212-220.

2 Див.: Він же. Класифікація снарядів до пневматичної зброї // Там само. - Х. : Право, 2009. - Вип. 9. - С. 262-268.

3 Тут і далі назва марки снарядів наведена відповідно до упаковки із додержанням мови та регістру. 
змішана (бавовна 53 \%, поліефірне волокно 47 \%) камуфляжна тканина «Грета» із малюнком «Ліс» і білий бавовняний трикотаж. При цьому виходили з того, що, по-перше, верхній одяг із камуфльованої тканини є уніформою для працівників силових відомств і охоронних структур, проти яких може бути застосована пневматична зброя, а, по-друге, що одяг, який виготовлено з тканини такого типу, останнім часом набув значного поширення і використовується рибалками, мисливцями, туристами та іншими, а, крім того, як робочий або для повсякденного носіння, - ще й пересічними громадянами. Бавовняний трикотаж $є$ поширеним матеріалом для різноманітного верхнього літнього одягу та натільної білизни.

Для дослідження використовували кулі з нових упаковок, що придбані в спеціалізованих зброярських торговельних закладах України. Із кожної упаковки «наосліп» брали по 20 куль. Перед дослідженням елементного складу всі відібрані зразки куль зважували на аналітичних вагах Axis $^{\circledR}$ серії $\mathrm{AN} 3$ точністю до 0,0001 г. Фактична маса куль наведена в табл. 1.

Таблиия 1

Технічні характеристики досліджуваних снарядів

\begin{tabular}{|c|c|c|}
\hline Марка снарядів & $\begin{array}{c}\text { Конструктивні } \\
\text { особливості }\end{array}$ & $\begin{array}{c}\text { Маса снарядів (2) } \\
\mathbf{n}=\mathbf{2 0} ; \mathbf{p}<\mathbf{0 , 0 5}\end{array}$ \\
\hline ЛЮМАН Field Target $0.68 \mathrm{~g}$ & куля ковпачкова & $0,679 \pm 0,00369$ \\
\hline Scarabey DS $0.62 \mathrm{~g}$ & куля типу «діаболо» & $0,622 \pm 0,00794$ \\
\hline Crosman Premier $0.68 \mathrm{~g}$ & «-"-》» & $0,673 \pm 0,00343$ \\
\hline Diabolo Standard & «-"-» & $0,503 \pm 0,00721$ \\
\hline
\end{tabular}

Для подальшого дослідження з 20-ти куль кожної марки відбирали по 3 зразки, маса яких не виходила за межі стандартного відхилення $(\sigma)$ від середнього значення $(\bar{X})$ при довірчому інтервалі $\mathrm{p}<0,05$. Із кусків камуфльованої тканини та бавовняного трикотажу, попередньо випраних у звичайній водопроводній воді, вирізали клапти розміром $15 \times 10 \mathrm{~cm}$, які використали для отримання експериментальних пневмострільних пошкоджень.

Постріли, обраними для дослідження кулями, здійснювали з відстані 2 м, на якій практично відсутня дія часток матеріалів снаряда й каналу ствола. Усього проведено 24 залікових досліди 8-ма серіями із 3-х пострілів по одному в кожну перешкоду. Перед початком експерименту та після кожної серії пострілів гвитівку ретельно чистили без застосування рушничного мастила й металевих приладів.

Дослідження відібраних зразків снарядів до ПЗ, пошкоджень і контрольних ділянок на перешкодах виконували на аналізаторі Expert 3XL за методикою енергодисперсійного рентгенофлуоресцентного елементного аналізу зі збудженням характеристичного випромінювання атомів проби фотонами гальмівного спектру малопотужної рентгенівської трубки та реє- 
страцією цього випромінювання напівпровідниковим детектором із термоелектричним охолодженням. Температура оточуючого повітря в приміщенні, де проводили дослідження, складала $+20-22^{\circ} \mathrm{C}$, вологість - не вище $80 \%$. Досліджувані зразки поміщали у вимірювальну камеру блоку вимірювання аналізатора на захисну плівку й закривали кришку. Зразки опромінювалися рентгенівським випромінюванням протягом 120 с при закритому фільтрі та відключеній подачі гелію за таких умов: калібрувальний режим - 54-45-CAL, напруга - 45 кеВ, ток - 44-68 мкА. Реєстрацію спектра рентгенівської флуоресценції здійснювали за допомогою програмного забезпечення аналізатора Expert 3XL. Параметри вимірювань і результати аналізу по кожній групі, що складалася з 3-х зразків снарядів та 3-х перешкод, надавались у вигляді файла-звіту в src-форматі. Результати опрацьовано з використанням пакета статистичних програм Microsoft Office. Отримані файли опрацьовані та збережені в архіві ПК.

Отже, методом РФСА в складі досліджуваних куль виявлено 11 елементів: Fe, Ga, As, Sr, Y, Zr, Sn, Sb, Os, Ir, Pb. Серед них основним (основою) є свинець $(\mathrm{Pb})$, масова частка якого складає 98-99\%. Із інших 10-ти елементів 9 є згаданими домішками до сплавів (лігатурою), а 1 - залізо (Fe) є примолом. Масова частка цих 10-ти елементів знаходиться в межах 0,033-1,26 \%. Свинець $(\mathrm{Pb})$ і залізо $(\mathrm{Fe})$ присутні в усіх досліджуваних кулях, а вид і кількість елементів, що належать до лігатур, у складі різних марок куль неоднакова. Так, ітрій (Y) та іридій (Ir) виявлено в усіх кулях, миш'як - (As) у кулях ЛЮМАН Field Target 0.68 g i Diabolo Standard, сурму (Sb) - у кулях Scarabey DS 0.62 g i Crosman Premier 0.68 g. Інші елементи знайдено в складі якоїсь однієї кулі: галій (Ga) - Scarabey DS 0.62 g, стронцій (Sr) - Crosman Premier $0.68 \mathrm{~g}$, цирконій $(\mathrm{Zr})$ - ЛЮМАН Field Target $0.68 \mathrm{~g}$, осмій $(\mathrm{Os})$ - Diabolo Standard.

Дослідженням контрольних ділянок на перешкодах виявлено такі елементи: камуфляжна тканина - Fe, $\mathrm{Cu}, \mathrm{Br}, \mathrm{Rh}, \mathrm{Cd}, \mathrm{Sn}, \mathrm{Te}$; трикотаж - $\mathrm{Ca}, \mathrm{Sc}$, Fe, Zn, Sr, Ag, Sn.

Пневмострільні пошкодження на перешкодах були наскрізними й мали вигляд дефектів круглої форми діаметром 0,2-0,3 см (трикотаж) і $0,3-0,4$ см (камуфляжна тканина) з темно-сірими поясками обтирання 0,1 см завширшки по краях. Дослідженням у пошкодженнях на камуфльованій тканині та трикотажі знайдені $\mathrm{Fe}$ й $\mathrm{Ga}, \mathrm{Y}, \mathrm{Zr}, \mathrm{Ir}, \mathrm{Pb}$, які відсутні на контрольних ділянках перешкод. Отже, єдиним елементом, присутнім у складі куль на ділянках пневмострільних пошкоджень і контрольних, $є$ залізо (Fe). Виходячи із цього його не було включено до подальшого порівняльного аналізу елементного складу куль і пошкоджень на перешкодах. Аналізу також не піддавалися ті елементи зі складу куль, які були відсутні в пошкодженнях на перешкодах. Результати аналізу наведено в табл. 2.

Порівняльний аналіз наведених у табл. 2 даних свідчить про таке. У складі всіх досліджуваних куль і в пошкодженнях на перешкодах з обох матеріалів одягу виявлено свинець (Pb), як основний елемент (основа) та ітрій (Y) зі складу лігатур. У той же час вид, кількість і масова частка інших елементів, що належать до лігатур, у складі пошкоджень на перешкодах неоднако- 
ва для різних марок куль. Так, у пошкодженнях на перешкодах, заподіяних кулями ЛЮМАН Field Target 0.68 g, додатково присутні цирконій (Zr) та іридій (Ir), а відсутній галій (Ga). У пошкодженнях, заподіяних кулями Scarabey DS $0.62 \mathrm{~g}$, додатково присутній лише галій (Ga), а відсутні цирконій (Zr) та іридій (Ir). У пошкодженях, заподіяних кулями Crosman Premier 0.68 g i Diabolo Standard, додатково присутній лише іридій (Ir), а відсутні галій (Ga) та цирконій (Zr). Отже, у складі кожної марки кулі або невеликої групи куль $\epsilon$ певні елементи, притаманні саме цим снарядам, які вони привносять у пошкодження на перешкодах.

Таблиия 2

Елементний склад суцільнометалевих снарядів
і пневмострільних пошкоджень на матеріалах одягу

\begin{tabular}{|c|c|c|c|c|c|}
\hline \multirow{3}{*}{$\begin{array}{c}\text { Куля, } \\
\text { матеріали одягу }\end{array}$} & \multicolumn{5}{|c|}{$\begin{array}{c}\text { Масова частка елемента в об'скті (\%) } \\
\text { та його призначення в сплаві }(\bar{X} \pm \sigma)\end{array}$} \\
\hline & \multirow{2}{*}{$\begin{array}{c}\text { Основа } \\
\mathbf{P b}^{82}\end{array}$} & \multicolumn{4}{|c|}{ Лігатура } \\
\hline & & $\mathbf{G a}^{31}$ & $\mathbf{Y}^{39}$ & $\mathrm{Zr}^{40}$ & $\mathbf{I r}^{77}$ \\
\hline $\begin{array}{l}\text { ЛЮМАН } \\
\text { Field Target } 0.68 \mathrm{~g}\end{array}$ & $\begin{array}{l}99,105 \\
\pm 0,082 \\
\end{array}$ & - & $\begin{array}{r}0,083 \\
\pm 0,027 \\
\end{array}$ & $\begin{array}{c}0,048 \\
\pm 0,009 \\
\end{array}$ & $\begin{array}{r}0,352 \\
\pm 0,069 \\
\end{array}$ \\
\hline Тканина камуфляжна & $\begin{array}{r}87,969 \\
\pm 0,614\end{array}$ & - & $\begin{array}{c}0,694 \\
\pm 0,134\end{array}$ & $\begin{array}{c}0,564 \\
\pm 0,133\end{array}$ & $\begin{array}{r}1,729 \\
\pm 0,165\end{array}$ \\
\hline Трикотаж & $\begin{array}{l}73,960 \\
\pm 0,849\end{array}$ & - & $\begin{array}{r}0,839 \\
\pm 0,179\end{array}$ & $\begin{aligned} & 1,138 \\
\pm & 0,200\end{aligned}$ & $\begin{array}{l}2,224 \\
\pm 0,193\end{array}$ \\
\hline Scarabey DS $0.62 \mathrm{~g}$ & $\begin{array}{c}98,701 \\
\pm 0,059\end{array}$ & $\begin{array}{c}0,056 \\
\pm 0,018\end{array}$ & $\begin{array}{c}0,115 \\
\pm 0,028\end{array}$ & - & - \\
\hline Тканина камуфляжна & $\begin{array}{l}83,297 \\
\pm 0,762\end{array}$ & $\begin{array}{r}0,138 \\
\pm 0,043\end{array}$ & $\begin{array}{r}0,931 \\
\pm 0,122\end{array}$ & - & - \\
\hline Трикотаж & $\begin{array}{l}58,125 \\
\pm 0,733\end{array}$ & $\begin{array}{r}0,219 \\
\pm 0,017\end{array}$ & $\begin{array}{r}0,378 \\
\pm 0,132\end{array}$ & - & - \\
\hline Crosman Premier $0.68 \mathrm{~g}$ & $\begin{array}{l}98,128 \\
\pm 0,084\end{array}$ & - & $\begin{array}{c}0,075 \\
\pm 0,026\end{array}$ & - & $\begin{array}{r}0,356 \\
\pm 0,066\end{array}$ \\
\hline Тканина камуфляжна & $\begin{array}{c}88,184 \\
\pm 0,580\end{array}$ & - & $\begin{array}{c}0,789 \\
\pm 0,136\end{array}$ & - & $\begin{array}{r}1,455 \\
\pm 0,166\end{array}$ \\
\hline Трикотаж & $\begin{array}{r}77,484 \\
\pm 0,708\end{array}$ & - & $\begin{array}{c}1,091 \\
\pm 0,190\end{array}$ & - & $\begin{array}{r}2,392 \\
\pm 0,195\end{array}$ \\
\hline Diabolo Standard & $\begin{array}{l}99,061 \\
\pm 0,086 \\
\end{array}$ & - & $\begin{array}{c}0,063 \\
\pm 0,028 \\
\end{array}$ & - & $\begin{array}{r}0,557 \\
\pm 0,069 \\
\end{array}$ \\
\hline Тканина камуфляжна & $\begin{array}{c}84,331 \\
\pm 0,713 \\
\end{array}$ & - & $\begin{array}{c}0,491 \\
\pm 0,128 \\
\end{array}$ & - & $\begin{array}{r}1,303 \\
\pm 0,162 \\
\end{array}$ \\
\hline Трикотаж & $\begin{array}{c}79,544 \\
\pm 0,708\end{array}$ & - & $\begin{array}{c}1,085 \\
\pm 0,190\end{array}$ & - & $\begin{array}{c}2,008 \\
\pm 0,201\end{array}$ \\
\hline
\end{tabular}


Таким чином, результати дослідження дозволяють дійти висновку, що свинцеві кулі до ПЗ здатні привносити до пошкоджень на окремих матеріалах одягу, зокрема камуфляжній тканині та бавовняному трикотажі, деякі елементи зі свого складу, які притаманні лише тій чи інший марці кулі. Це, у свою чергу, розширює можливості судово-медичної експертизи під час вирішення питання щодо визначення виду та марки снаряда (кулі, кульки та ін.) або невеликої групи схожих за елементним складом снарядів, які заподіяли пневмострільні пошкодження на досліджуваних об’єктах. Крім того, у випадках, коли достеменно відома марка застосованого снаряда, а в пошкодженні на перешкоді виявлено якісь елементи, що не входять до складу саме цього снаряда, можна дійти висновку, що із наданого зразка зброї після останнього чищення виконувалася стрільба ще й іншими снарядами, які містять знайдені на перешкоді елементи.

\section{ОПРЕДЕЛЕНИЕ ВИДА И МАРКИ СНАРЯДОВ МЕТОДОМ РЕНТГЕНОФЛЮОРЕСЦЕНТНОГО СПЕКТРАЛЬНОГО АНАЛИЗА ПРИ ИССЛЕДОВАНИИ ПНЕВМОСТРЕЛЬНЫХ ПОВРЕЖДЕНИЙ НЕКОТОРЫХ МАТЕРИАЛОВ ОДЕЖДЫ}

\section{И. Н. Козаченко}

Выполнен ренетгенофлюоресцентный спектральный качественный и количественный анализы (РФСА) элементного состава 4-х марок пуль для пневматического оружия отечественного и иностранного производств, а также имитаторов распространенных материалов одежды - камуфлированной ткани и хлопчатобумажного трикотажа. Установлено, что свинцовые пули для пневматического оружия способны привносить в повреждения на некоторых материалах одежды, в частности на камуфлированной ткани и хлопчатобумажном трикотаже, отдельные элементы из своего состава, присущие только той или иной марке пули. Это расширяет возможности судебно-медищинской экспертизы при решении вопроса об определении вида и марки пули или небольшой группы сходных по элементному составу, причинивщих пневмострельные повреждения на исследуемых объектах.

Ключевые слова: рентгенофлюоресцентный спектральный анализ, элементный состав, пули калибра 4,5 мм, пневмострельные повреждения, камуфлированная ткань, хлопчатобумажный трикотраж.

\section{DERTERMINATION OF THE TYPE AND MARK OF PROJECTILES BY THE METHOD OF X-RAY FLUORESCENT SPECTRAL ANALYSIS IN THE STUDY OF PNEUMATICALLY SHOT INJURIOUS OF SOME CLOTHING MATERIALS}

\section{Kozachenko I. M.}

$X$-ray fluorescence spectral analysis (RFSA) is used in the study of pneumatical shot injuries of various objects in the forensic medical and criminalistic examinations because this method allows operatively and accurately determine the elemental composition of the object, keeping it unchanged. The aim of the research is to determine the elemental composition of separate projectiles belonging to the air guns of $4.5 \mathrm{~mm}$ caliber and the presence 
of similar elements in pneumatical shot injuries to the simulators of popular clothing fabrics which will give a possibility to determine the projectile mark or a group of projectiles with similar composition in traces on objects by using RFSA. With the help of the elemental composition analyzer Expert $3 X L$, the composition of lead bullets for the air guns of $4.5 \mathrm{~mm}$ caliber for ЛЮMAH Field Target $0.68 \mathrm{~g}$ and Scarabey DS $0.62 \mathrm{~g}$ (Ukraine) and Crosman Premier $0.68 \mathrm{~g}$ (USA) and Diabolo Standard (Czech), as well pneumatical shot injuries to the clothing materials - camouflage fabric and cotton knitwear, is determined. It's established that lead bullets for pneumatic weapon are able to bring to the clothing materials injuries some of the elements of their composition are unique to a particular mark of a ball. This expands the possibilities of forensic medical examination in solving the issue of determining the type and mark of the projectile or a small group of the projectiles which are similar in elemental composition, and have caused pneumatical shot injuries to the studied objects. Moreover, in the cases where the mark of the used projectile is exactly known, and some elements which do not make up composition of its structure, are identified in the injuries upon obstacle, it can be concluded that the given sample of weapon after its last cleaning was shooting by other projectiles.

Keywords: X-ray fluorescent spectral analysis, elemental composition, bullets of $4.5 \mathrm{~mm}$ caliber, pneumatical shot injuries, camouflage fabric, cotton knitwear. 